\title{
Mineral Business Permits and its Legal Implications to Improve Welfare of Indonesian People
}

\author{
Untoro \\ Faculty of Law \\ Jakarta Islamic University \\ Jakarta Indonesia \\ untoro_uid@yahoo.co.id
}

\author{
Farhana \\ Faculty of Law \\ Jakarta Islamic University \\ Jakarta Indonesia \\ farhana961@uid.ac.id
}

\author{
Hamdan Azhar Siregar \\ Faculty of Law \\ Jakarta Islamic University \\ Jakarta Indonesia \\ hamdan_sir@yahoo.co.id
}

\begin{abstract}
Permission terminology is distinguished by the terminology of mining power. This terminology changes in line with the issuance of Law No. 4 of 2009 on Mineral and Coal Mining which replaces Law Number 11 Year 1967 on Basic Provisions of Mining. The implication is that the licensor can no longer easily to issue a mining business permit, because it has to pay attention to the consequences on every license made. Therefore, implicitly, the licensor will in the beginning of the permit application consistent with the purpose of mineral and coal legislation in an effort to improve the welfare for the people of Indonesia. This research is a normative legal research with philosophical and conceptual approach. The purpose of this research was to philosophically analyze the management of mining activities in Indonesia. The result of the research revealed that the change of nature and form of the concession poured one of them in the form of mining authority, it becomes a form of permit resulting in institutional strengthening in the realization of Article 33 paragraph (3) and paragraph (4) of the 1945 Constitution of the Republic of Indonesia as the legal basis implementation of the principle of corporate social responsibility. Nevertheless, Law No. 4 of 2009 on Mineral and Coal Mining does not explain explicitly about what is meant by a business entity, whether in the form of Limited Liability Company (PT), CommanditeireVennotcshap (CV) or Firma. Since it is related to the implementation of corporate social responsibility principle related to the provision of Article 74 of Law Number 14 Year 2007 regarding Limited Company, CV and Firma. They have no obligation to implement the principles of corporate social responsibility.
\end{abstract}

Keywords - mining business permits, implications, people's welfare

\section{INTRODUCTION}

The issuance of Law Number 4 of 2009 on Mineral and Coal Mining is one of the mandates of Article 33 paragraph (3) and paragraph (4) of the 1945 Constitution of the State of the Republic of Indonesia. It is the legal basis for the state to control and manage the natural resources in the field of mining based on economic democracy. This indicates that the state has a function as a regulator. As a regular, it is prosecuted in issuing its policy is always aimed at the justice and welfare of the people of Indonesia. This action is as the objectives of the state of Indonesia as mandated in the fourth paragraph of the preamble of the 1945 Constitution of the State of the Republic of Indonesia, namely the promotion of public welfare. Promoting public welfare is a feature of Indonesia as a welfare state
R. Kranenburgas a welfare state figure stated that the state must actively pursue welfare, to act fairly that the whole society can feel equally and equitably, not the welfare of a particular group, but all the people[1].

Law No. 4 of 2009 on Mineral and Coal Mining as a legal basis for managing mining cannot be separated from the principles of economic democracy as stated in Article 33 Paragraph (4) of the 1945 Constitution of the Republic of Indonesia which states that:

"The national economy is organized based on economic democracy with the principles of togetherness, efficiency, justice, sustainability, environmental insight, independence, and by maintaining a balance of progress and national economic unity"

So it is stated in the general explanation of Mineral and Coal legislation, the exploration of mineral and coal must able to provide economic and social benefits, accelerate the development of the region and encourage the economic activities of the community/small and medium entrepreneurs as well as provide sustainable development. In other words, in the mining management activities, there are several principles that must be considered, namely environmental principles, transparency and community participation[2].

Elucidation of Law Number 4 Year 2009 on Mineral and Coal Mining gives a hint of the concept of causality law in the management and exploitation of natural resources[2]. In the sense of causal relationships affecting each other, the sustainability of companies engaged in mining is influenced by the exposure of natural resources itself. If the carrying capacity of natural resources is damaged, it will result in public income disappear. The people will assume that the company as the cause of all sorrow they got[3]. Therefore, there is a paradigm shift in the management of mining activities from the effort to collect the big profits to the greatest prosperity of the people and the interests of all relevant stakeholders. The growing paradigm is the nature of corporate social responsibility from voluntary to mandatory. The nature of mandatory corporate social responsibility in Law No. 4 year 2009 on Mineral and Coal Mining appears from three matters, namely: the requirements for application of mining business permit; liability of the licensor; and obligation of license holder. The paradigm is actually a "protection" philosophical system that includes certain ontologies, epistemologies and methodologies. Each consists of a series of basic beliefs or worldviews that cannot be 
exchanged with basic beliefs of ontology, epistemology and other paradigm methodologies[4].

Based on the above description, then the problem that arises in this study was how the 1945 Constitution of the Republic of Indonesia plays a role as the basis of the constitution in the application of corporate social responsibility? What are the principles of corporate social responsibility in Law Number 4 Year 2009 regarding Mineral and Coal Mining in realizing justice?

\section{RESULTS OF RESEARCH AND DISCUSSION}

\section{A. The 1945 Constitution of the Republic of Indonesia is as the Foundation of the Constitution in the Application of corporate social responsibility}

The Elucidation of the 1945 Constitution of the Republic of Indonesia affirms that Indonesia is a legal state that can be categorized as a modern legal state. The concept shows Indonesia as a modern legal state, the goal of the Indonesian state is contained in the fourth paragraph, which normatively in the effort to promote the general welfare and social justice is outlined in Article 33 of the Constitution of the Republic of Indonesia Year 1945. [2]. In order for the country's objectives to be achieved, there are strategic tasks to be achieved, namely to maintain security and order; cultivate the welfare and prosperity of its people; carry out defenses to guard against possible external attacks with modern equipment of defense equipment; uphold justice exercised by judicial bodies.[5]. However, to be considered in the context of the management of natural resources (Minerba) which is an unfulfilled resource, it must be done optimally by applying the principles of justice and sustainability so as to achieve sustainable prosperity of the people. Applying the principle of sustainability means applying the principle of sustainable development. The importance of applying the principle of sustainable development is because it contains equity, participation, diversity, integration and long-term perspective.[6].

The concept of Article 33 of the 1945 Constitution of the Republic of Indonesia is the constitutional basis of the state's control over the earth, water and natural resources contained therein. Mohammad Hatta gave the formula, controlled by the state does not mean the state becomes entrepreneurs, businessmen or ondernemer. It is, however, more accurate to say that state power exists in the power of making rules for the smoothness of the economic sector, the arrangement which forbids the exploitation of the weak people by the capital funder.

Thus, the right to control the state over economic resources (mining) can be interpreted as state power to make regulations. The regulation is on the obligation to apply corporate social responsibility. This means, institutional strengthening has been made to realize Article 33 paragraph (3) and (4) of the 1945 Constitution of the Republic of Indonesia, with the issuance of Law No. 4 of 2009 on Mineral and Coal Mining as the legal basis for the application of social responsibility company. The consequence of institutional strengthening is juridically based on the transformation of corporate social responsibility from voluntary to mandatory or legal obligation.The juridical transformation is strengthened by the issuance of the decision of the Constitutional Court which rejects the case Number 53 / PUU/-VI/2008 concerning the Application for
Judicial Review of Law Number 40 Year 2007 regarding Limited Liability Company against Article 28 D Paragraph (1), Article 28 I Paragraph 2), and Article 33 paragraph (4) of the 1945 Constitution of the State of the Republic of Indonesia.

\section{B. Corporate Social Responsibility Principles in Law Number 4 Year 2009 on Mineral and Coal Mining}

Philosophically, the management of mining activities is to achieve the greatest prosperity of the people of Indonesia. Therefore, the government as a regulator and facilitator is required to organize in such a way that the natural wealth is not only enjoyed by licensing companies but also by the community. Hence, in the management of mining activities, it cannot be separated from the principles of economic democracy. In the principle of the welfare state is embodied the notion of political democracy and economic democracy, which historically received unanimously by both members of BPUPKI and members of the PPKI which convened on 18 August 1945. Thus, social justice through the realization of the welfare state is an ethical imperative of the Pancasila and Act-The basic principle of the republic of Indonesia Year 1945. Therefore, the values of kinship of Indonesia contained in the principles of Pancasila should be the basis in realizing justice and social welfare.[7].

The form of justice according to the formulation of Center for Populist Economic Studies, Brawijaya University, justice is at least manifested in three forms. These three forms give birth to three justice of exchange, social justice, and distributive justice. [7]. The three forms of justice in question are:

1. Justice in the economic relations between people in person by always giving to others what should be accepted as their rights. This is what gave birth to justice exchange.

2. Justice in economic relations between people and society, by always giving and implementing everything that promotes prosperity and prosperity together. This creates social welfare.

3. Justice in economic relations between society and its citizens, by always sharing all the pleasure and burden evenly in accordance with the nature and capacity of each. This is what gave birth to distributive justice.

The principle of corporate social responsibility in relation to the management of mineral and coal resources should take into account several principles of corporate social responsibility. The following table describes some of the principles to be considered.

\begin{tabular}{|c|c|c|c|}
\hline \multicolumn{4}{|c|}{ Some Aspects and Principles of Corporate Social Responsibility } \\
\hline \multirow{6}{*}{ Principle } & $\begin{array}{l}\text { Economic } \\
\text { Aspect }\end{array}$ & Social Aspect & Environment Aspect \\
\hline & $\begin{array}{l}\text { Human capital } \\
\text { principles }\end{array}$ & $\begin{array}{l}\text { Human capital } \\
\text { principles }\end{array}$ & $\begin{array}{l}\text { Standarizarion } \\
\text { principles }\end{array}$ \\
\hline & $\begin{array}{l}\text { Partnership } \\
\text { principles }\end{array}$ & $\begin{array}{l}\text { Education } \\
\text { principle }\end{array}$ & Disclosure principles \\
\hline & \multirow{3}{*}{$\begin{array}{l}\text { Principleof good } \\
\text { corporate } \\
\text { governance }\end{array}$} & \multirow{3}{*}{$\begin{array}{l}\text { Principleof } \\
\text { public } \\
\text { information }\end{array}$} & $\begin{array}{l}\text { Precautionary } \\
\text { principle }\end{array}$ \\
\hline & & & $\begin{array}{l}\text { Principle of } \\
\text { environmentally } \\
\text { friendly technology }\end{array}$ \\
\hline & & & $\begin{array}{l}\text { Principle of law- } \\
\text { abiding }\end{array}$ \\
\hline
\end{tabular}




\section{CONCLUSION}

This research generated two conclusions, firstly Natural resource management and exploitation (mining) follows the concept of causality law, that there is a mutual relationship between the company's sustainability in the mining sector and the maintenance of natural resources of mining. So that there is a paradigm shift in the management of mining activities from collecting profits as much as possible to the greatest prosperity of the people and all relevant stakeholders. Second, the management of mining activities philosophically is to achieve the greatest prosperity of the people of Indonesia. It requires enforcement of the principle of corporate social responsibility in relation to the management of mineral and coal resources. Thus, efforts to achieve justice and social welfare must be based on the values of the Indonesian family in Pancasila.

\section{REFERENCES}

[1] B. Limbong, Politik Pertanahan. Jakarta: Margaretha Pustaka, 2014.

[2] B. Azheri, Principle Pengelolaan Mineral dan Batu Bara. Kajian Filosofis terhadap Undang-Undang Nomor 4 Tahun 2009. Jakarta: PT. Raja Grafindo Persada, 2016.

[3] W. Wordworth, Kata Pengantar dalam "Corporate Social Responsibility (CSR) dalam praktik di Indonesia. Jakarta: Elex Media Komputindo, 2008.

[4] E. Indarti, "Diskresi dan Paradigma. Sebuah Telaah Filsafat Hukum," 2010

[5] T. S. B. Johan, Perkembangan Ilmu Negara Dalam Peradaban Globalisasi Dunia. Jakarta: Deeppublish, 2018.

[6] Raihan, Lingkungan dan Hukum Lingkungan. Jakarta: Universitas Islam Jakarta, 2011.

[7] Y. Latif, Negara Paripurna. Historisitas, Rasionalitas, dan Aktualitas Pancasila, 4th ed. PT Gramedi Pustaka Utama, 2012. 